Volume: 11 Issue: 2 Year: 2014

\title{
Humiliation in the virtual world: Definitions and conceptualization
}

\author{
Julie Alev Dilmaç
}

\begin{abstract}
The cyberspace represents a platform for social relations which permit to be in touch with the World, to be "seen" by others and to "see" others. As new technologies emerge, ways of viewing are revised, especially through screens: though it has facilitated communication, the main innovation of the virtual world has been seeing, hearing and showing everything with the individual at the center of permanent interactions. But this overexposure can be dangerous: in attempting to be as much a part of the virtual world through self-exposition, individuals expose themselves to potential sources of humiliation. This exploratory analysis will outline the main literature concerning humiliation in the virtual world. By looking at the interaction occurring in the Internet, it will be shown that a dialectic exchange between "being seen" and "seeing" others exists and that it can be a trap for the individuals which leads to humiliation, henceforth called "cyberhumiliation". It will be also attempted to outline the differences between cyber-humiliation and humiliation in the contemporary society.
\end{abstract}

Keywords: Cyber-humiliation; Cyberbullying; Cyber-mobbing; Harassment; Internet; Gaze; Interactions.

\section{Introduction}

In the contemporary society, individuals want to be a part of some networks. They are trying to stay permanently in touch with others. This interface has allowed everyone, and especially the least daring, to express themselves (on forums, in chat rooms), to worship, to create (their own blogs, for example), but also to protest, to join forces, to get angry. By doing so, they are trying to obtain the social recognition. The new technologies, and especially Internet, contribute as well to the maintenance and development of these relations: the Internet constitutes a virtual "place" for sociability. It is a platform for interactions: it leads to "being in touch" with the World and with others. Through Internet, individuals communicate with others; but they can also "see others" and

\footnotetext{
${ }^{1}$ Ph.D., Assistant Professor,Cyprus International University, Department of Social Work, Head of Department,
} jadilmac@gmail.com 
Dilmaç, J. A.(2014). Humiliation in the virtual world: Definitions and conceptualization. International Journal of Human Sciences, 11(2), 1285-1296. doi: 10.14687/ijhs.v11i2.3036

being "seen by others". For me, this aspect related to the ways of "viewing" has to be highlight to understand the new technologies and their use (Dilmaç 2014a).

Today, individuals use different websites to be "viewable" by all like Facebook or Instagram. They search for the gaze of others through Internet because it has become necessary to "live" in the virtual world in order to be "truly alive" and to be recognized.

This importance of the "look" leads to the emergence of new practices and new kind of behaviors: First, today, individuals want to be "followed", "liked" "shared", but also "commented". If our posts are neither "followed" nor commented or shared, it means we are invisible in others' eyes. This feeling is all the more unbearable in a world where any connection with others is established by views.

Secondly, on Internet "views" are counted in terms of which determines the "popularity quotient". Third, individuals use virtual "walls" to expose themselves: nowadays, the wall is no longer a boundary separating individuals or hiding them from others; it is now a place to exhibit and offer oneself to others' gaze through sharing documents, images or commentaries (Dilmaç 2014b).

Another fact, the concept of reputation tends to be redefined as well: to "have a good reputation" in the virtual world, it is not enough to be an individual who is praised by others for irreproachable ethics; to build an e-reputation, you need to be the most seen and the most viewed, for whatever reason. For these reasons, many Internet users are eager to stand naked and unveil intimate parts of their lives. In this world, presentations of the self are no longer based on a private-public distinction.

So today, evidently, existing on the Internet means existing in the eyes of the Other, constantly and sometimes in the most intimate detail. Individuals want to be viewed by others. As new technologies emerge, ways of viewing are revised, especially through screens: though it has facilitated communication, access to information and has made it possible to store a large quantity of data, the main innovation of the Internet has been, in ordinary life as in the media, "seeing, hearing and showing everything" (Uhl 2002).

But sometimes visibility can be a trap: in attempting to be a part of the virtual world, individuals expose themselves to constant judgment, but also to potential sources of humiliation. Internet, because of the over exposition it permits, can be potential vehicle for individuals to engage in risky and destructive behaviors (Duncan 2008). According to recent researches, these kinds of incidences of abuse on Internet have been increasing at an important rate (Goodstein 2007).

New terms are used today to talk about these interactions: "cyber-bullying," "cyber-mobbing", "cyber-intimidation", "cyber-stalking” or even "cyber-humiliation." All these practices aim to discredit the person in the virtual world. 
Dilmaç, J. A.(2014). Humiliation in the virtual world: Definitions and conceptualization. International Journal of Human Sciences, 11(2), 1285-1296. doi: 10.14687/ijhs.v11i2.3036

\section{A- Definition of the concept: what is cyber-humiliation?}

'Bullying' is usually defined as being intentional aggressive act behaviour that is carried out by a group or an individual repeatedly against a victim who cannot defend him or herself (Olweus 1993). Traditional forms of bullying exist: the intimidation can be physical, verbal or relational.

Cyber-humiliation corresponds to the degradation of a person or group, in a process of subjugation that damages or destroys pride, honor or dignity. The aggression occurs through modern technological devices, like mobiles phones or the Internet. The cyberbullying can occurs through distortion of photographs, post of false information, and coercive actions like sending threatening or aggressive messages online (Slonge and Smith 2008). Like mobbing, cyber-humiliation reveals itself in various ways including gossiping, teasing, ostracizing someone or accusing someone of being a liar (Kilic 2009). It corresponds to a repetitive attack on the self-confidence, dignity and self-respect of the tormenter (Field 2004; Hirigoyen 2003); it is characterized by the effort involved in the destruction of the victim's self-underlying the desire "to dominate, to subjugate and to eliminate" (Fields 2004; Hirigoyen 1998). These kind of relations provoke in the victim feelings of confusion, anger, sadness and diminished self-esteem (Carlson 1987).

Humiliation corresponds to a specific situation in which an individual or a group is faced with an unequal relation with someone who exercises control and the other person who is subject to this control (Ansart 2006: 132). The cyber-humiliation is based on an imbalance of power (Smith and Sharp 1994; Rigby 2002). This interaction is based on psychological violence which can be defined as the repetitive attack of a person with the intention to damage another one (Davenport, Schawartzand Elliott2003; Leymann 1996). Leymann analyzed this phenomenon as well: according to him, mobbing is the repetitive, hostile, unethical treatment of others (Leymann 1996; Davenport et al. 2003; Jarreta, Garcia-Campayo, Gasconand Bolea 2004; Hecker 2007), the psychological tormenting of a person which occurs through one or more individuals'. The main characteristic of humiliation is that is a process in which the victim has no means of responding to the attack, and must passively endures it. This passivity stronger when humiliation is formulated on the Internet: in the case of someone taking over their identity or exposing a compromising image in their name, the victim can neither make a comeback nor even know the identity of the aggressor.

For Smith, Mahdavi, Carvalho and Tippett (2006) seven different subcategories of cyber bullying exist: email bullying, bullying through instant messaging and bullying via websites, picture/video clip bullying (through mobiles phones), text message bullying, phone call bullying (via mobile phones), chat room bullying.

For us, in the virtual world, multiple forms of humiliation can be seen: 
Dilmaç, J. A.(2014). Humiliation in the virtual world: Definitions and conceptualization. International Journal of Human Sciences, 11(2), 1285-1296. doi: 10.14687/ijhs.v11i2.3036

In some cases, individuals have not consented to appear on the Web and nonetheless appear against their will on networks: here, others express themselves in their name. This is the case with "false profiles". The image of the person is disseminated by the Other in order to stigmatize it;

Revealing images and personal information in the name of a third party also implies imposed humiliation: sharing photos or intimate videos filmed without the person knowing; in which their private lives are exposed (Haroche 2006: 32) has become common practice in the digital era. The case of 17-year-old Rehtaeh Parsons, who hung herself after a video of sexual violence against her was posted online, is one of many examples of cyber-humiliation;

This is also the case of psychological harassment (Hirigoyen 2004) or online harassment (Sengupta and Chaudhuri 2011): here, victims discover that they are "offered" for others to contemplate the spectacle of their distress, their humiliation. Victims can witness their own humiliation and at the same time be devoured by other Internet users' viewings, with their opportunities to applaud, comment, or encourage the violence. The victim's humiliation is greatly increased;

At another extreme, having one's profile erased is yet another form of humiliation: imagine suddenly noticing that you "no longer exist" and have disappeared from the network, to everyone's indifference, in a society where recognition essentially means being viewed. In this case, the disappearance of your image means an unbearable invisibility. You can no longer be seen. This inattention can signify ignorant, scornful indifference, or even denial of the individual as a human being (Ellison 1991).

In all these situations, individuals lose control of their image: whether it is determined by an exterior force, divulged to the world or totally ignored, the individual is subject to situations of violence established through viewing, a form of humiliation reinforced by the incertitude of what will happen to the images.

Different kind of humiliating practices have been also reported by the National Crime Prevention Council':

- Sending someone mean or threatening emails or text messages

- Excluding someone from an friend list or blocking them

- Revealing personal or embarrassing information concerning someone and sending it to others

- Pirating someone's email account to send untrue messages while posing as that person

- Make fun of another person in the virtual world

- Rating peers as prettiest or ugliest in websites.

\footnotetext{
${ }^{2}$ http://www.ncpc.org/topics/cyberbullying/what-is-cyberbullying
} 
Dilmaç, J. A.(2014). Humiliation in the virtual world: Definitions and conceptualization. International Journal of Human Sciences, 11(2), 1285-1296. doi: 10.14687/ijhs.v11i2.3036

To explain this kind of practices, Rivers and Noret (2009) have indicated that cyberbullying may form part of 10 categories of behaviors:

Threat of physical violence; Abusive or hate-related; Name-calling (including homophobia); Death threats; Ending of platonic relationships; Sexual acts; Demands; Threats to damage existing relationships; Threats to home/family; Menacing chain messages.

\section{The case "Rebecca Sedwick"}

To get a better understanding of this concept, the focus on a specific case of cyberbullying is needed. For the purpose of this article, the case of Rebecca Sedwick has been chosen. The victim was 12 years old when she committed suicide after having being tormented online for months by two teenage girls. The cyberbullying started when Rebecca had been seen with a boy who was dating one of the stalker. The offenders started to send threatening messages on Facebook and encouraged her to kill herself. They terrorized their victim by calling her names, especially "ugly", and telling her "to drink bleach and die". Rebecca was also victim of physical attacks in school. After her suicide, one of the tormenters continued to post comments about Rebecca online, confirming the bulling; one of the message was "Yes, I bullied Rebecca and she killed herself but I don't give a..." The two harassers were arrested without feeling guilty about their acts.

\section{B- Cyber-humiliation worldwide}

It seems that this kind of intimidation exists in every society. Several researches in different countries aimed to describe these practices.

In his Annual Bullying Survey ${ }^{3}$, Liam Hackett (2013) showed that taken from over 2,000British teens $69 \%$, namely 7 in 10 have experienced cyberbullying.

$20 \%$ of which had been very extreme.

$37 \%$ of this experience bullying frequently.

$20 \%$ also had underwent extreme cases \& were twice as likely to be bullied in Facebook as any other sites.

With 54\% had experienced extreme cases and were twice as likely to be intimidated in Facebook as any other sites.

\footnotetext{
${ }^{3}$ http://www.ditchthelabel.org/downloads/Annual-Bullying-Survey-2013b.pdf
} 
Dilmaç, J. A.(2014). Humiliation in the virtual world: Definitions and conceptualization. International Journal of Human Sciences, 11(2), 1285-1296. doi: 10.14687/ijhs.v11i2.3036

To understand the problem of cyber humiliation, Microsoft (2012) organized a worldwide survey to analyze online behaviors among youth. According to this commissioned research ${ }^{4}$,

$\checkmark \quad 54$ percent of children age 8 to 17 in twenty-five countries ${ }^{5}$ express concern that they will be bullied online.

$\checkmark \quad 4$ in 10 say someone was mean to them online.

$\checkmark \quad 24$ percent admit to having bullied someone else online at one time or another.

This survey contributed also to highlight the different practices of young population related to cyber bullying:

Graphic 1. Online bullying Metrics: Worldwide Averages

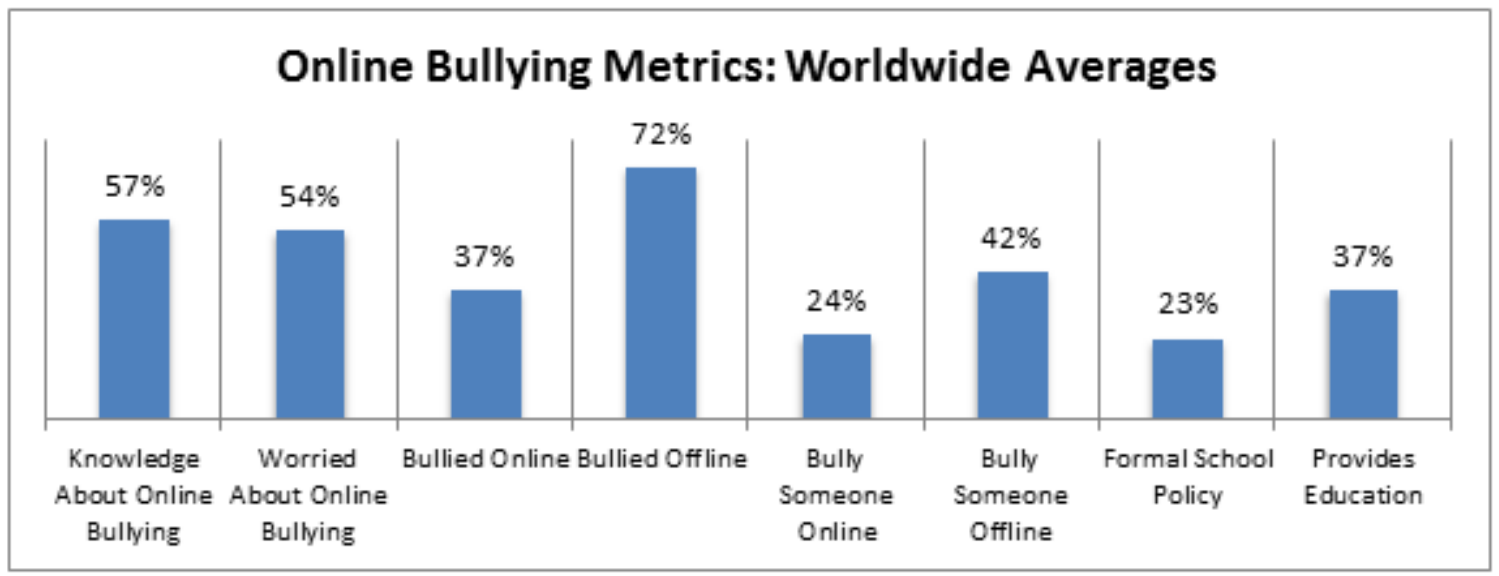

Source: Online Bullying Among Youth 8-17 Worldwide (Microsoft (2012))

\section{C- The cyber-humiliation: A new form of intimidation?}

The cyber-humiliation, in my view, differs from the traditional humiliation: the first difference that could be noticed is that unlike traditional form of humiliation, where once the victim gets home they are away from the bullying, with the cyber-humiliation the victim may continue to receive emails or messages wherever he/she is. As mentioned in the federal government website's Stopbullying, cyberbullying "can happen 24 hours a day, 7 days a week, and reach a kid even when he or she is alone. It can happen any time of the day or night."

Another is the invisibility of those doing the bullying: on Internet, the victim does not see or know who the aggressors are. The cyber-humiliation is not a face to face experience: the aggressor is provided with anonymity and invisibility.

${ }^{4}$ Online Bullying Among Youth 8-17 Worldwide (February 2012, 25 Countries/Regions)

${ }^{5}$ For this survey, the sample of youth was surveyed in Argentina, Australia, Brazil, Canada, China, Czech Republic, Egypt, France, Germany, India, Italy, Japan, Malaysia, Morocco, Norway, Pakistan, Poland, Qatar, Russia, Singapore, Spain, Turkey, U.A.E., U.K., and U.S. 
Dilmaç, J. A.(2014). Humiliation in the virtual world: Definitions and conceptualization. International Journal of Human Sciences, 11(2), 1285-1296. doi: 10.14687/ijhs.v11i2.3036

Another common characteristic of cyber-humiliation is the breadth of potential audience: the audience that may see videos shared with the intention to embarrass a person can be very large: "Cyberbullying messages and images can be posted anonymously and distributed quickly to a very wide audience. It can be difficult and sometimes impossible to trace the source".

Following on from this, compared to most traditional bullying, the humiliation on Internet is reinforced by pictures and comments: pictures of the humiliation are shared with anonyms and the victim cannot erase them. In this situation, the victim has no chance to control the destiny of his/her images and the humiliation is "permanently" lived.

We tried to sum up the differences and similarities between traditional humiliation and cyberhumiliation in the table below:

Table 1.The Different Characteristic Features of Humiliation and Cyber-bumiliation

\begin{tabular}{|c|c|c|}
\hline & $\begin{array}{l}\text { TRADITIONAL } \\
\text { HUMILIATION }\end{array}$ & CYBER-HUMILIATION \\
\hline TYPES OF HUMILIATION & $\begin{array}{l}\text { The attacks can be verbal, } \\
\text { physical, indirect or } \\
\text { relational (Rigby 1997) }\end{array}$ & $\begin{array}{l}\text { The cyber-humiliation is not } \\
\text { characterized by physical attacks but } \\
\text { could be much more violent than } \\
\text { humiliation in face-to-face relations. } \\
\text { It leads to a symbolic death. Destroys } \\
\text { the social and virtual image of the } \\
\text { person, his/her self-esteem and } \\
\text { dignity. }\end{array}$ \\
\hline $\begin{array}{c}\text { CHARACTERISTICS OF } \\
\text { HUMILIATION }\end{array}$ & $\begin{array}{l}\text { The humiliation can involve } \\
\text { one person against another } \\
\text { one or against a group of } \\
\text { individual. The traditional } \\
\text { form of humiliation } \\
\text { corresponds to repetitive } \\
\text { attacks which aim to destroy } \\
\text { the self-esteem of a person. }\end{array}$ & $\begin{array}{l}\text { The cyber-humiliation can be much } \\
\text { more destructive for the victim than } \\
\text { traditional humiliation because in this } \\
\text { case, the tormentor can use pictures } \\
\text { and movies as tools for the } \\
\text { harassment. This fact has a more } \\
\text { destructive impact on the individual's } \\
\text { self-esteem than the public } \\
\text { humiliation in face to face relations } \\
\text { (Sticca and Perren 2013). }\end{array}$ \\
\hline $\begin{array}{l}\text { RELATION BETWEEN THE } \\
\text { VICTIM AND THE } \\
\text { AGGRESSOR }\end{array}$ & $\begin{array}{l}\text { The relation between the } \\
\text { victim and the tormentor is } \\
\text { based on a face-to-face } \\
\text { interaction. In most cases, } \\
\text { the victim knows his/her } \\
\text { harasser. }\end{array}$ & $\begin{array}{l}\text { Invisibility of the persecutor(s). The } \\
\text { victim does not know who the } \\
\text { tormentor could be nor the reason of } \\
\text { his/her attacks. Some researchers } \\
\text { have showed that almost } 60 \% \text { of the } \\
\text { victims did not know who their } \\
\text { harasser could be. (Tokunaga 2010; } \\
\text { Kiriakidis and Kavoura 2010; }\end{array}$ \\
\hline
\end{tabular}


Dilmaç, J. A.(2014). Humiliation in the virtual world: Definitions and conceptualization. International Journal of Human Sciences, 11(2), 1285-1296. doi: 10.14687/ijhs.v11i2.3036

\begin{tabular}{|c|c|c|}
\hline & & $\begin{array}{l}\text { Juvonen and Gross, 2008). It is also } \\
\text { proved that cyber-aggressors were } \\
\text { involved in cyber-humiliation just } \\
\text { "for fun" (Suzuki et al. 2012; } \\
\text { Pujazon-Zazik and Park 2010) }\end{array}$ \\
\hline AUDIENCE & $\begin{array}{l}\text { In this situation, some } \\
\text { persons can witnessed the } \\
\text { humiliation and react to help } \\
\text { the victim to protect } \\
\text { her/himself. (Sourander et } \\
\text { al. 2010; Sticca and Perren } \\
\text { 2013) }\end{array}$ & $\begin{array}{l}\text { The humiliation can be witnessed by } \\
\text { anonymous population. The } \\
\text { humiliating pictures can be shared } \\
\text { with a large audience. Moreover, } \\
\text { even people who do not want to } \\
\text { participate in the aggression find } \\
\text { themselves involved, against their } \\
\text { will, in the process by becoming } \\
\text { spectator of the cyber-humiliation. }\end{array}$ \\
\hline $\begin{array}{l}\text { DURATION OF } \\
\text { HUMILIATION }\end{array}$ & $\begin{array}{l}\text { The humiliation lasts only } \\
\text { the time of the interaction } \\
\text { between the victim and the } \\
\text { aggressor. }\end{array}$ & $\begin{array}{l}\text { As the cyber-humiliation occurs in } \\
\text { Internet, emails, pictures, videos, } \\
\text { messages can be posted and sent at } \\
\text { any time during the day. This fact } \\
\text { tends to increase the fear and the } \\
\text { sensation of "being tracking" of the } \\
\text { victim (Suzuki et al. 2012; Tokunaga } \\
\text { 2010). }\end{array}$ \\
\hline FEEDBACK AND EMPATHY & $\begin{array}{l}\text { By seeing the reaction of the } \\
\text { victim provoked by his/her } \\
\text { attacks, the tormentor can } \\
\text { end the harassment. A } \\
\text { relation of empathy can be } \\
\text { established. }\end{array}$ & $\begin{array}{l}\text { As the victim and the aggressor } \\
\text { cannot see each other, the persecutor } \\
\text { cannot be aware of the consequences } \\
\text { caused by his/her actions. Without } \\
\text { such direct feedback, there may be } \\
\text { fewer opportunity for empathy. }\end{array}$ \\
\hline RESPONSE TO HUMILIATION & $\begin{array}{l}\text { In most of the cases, the } \\
\text { victim can identify his/her } \\
\text { aggressor and can seek } \\
\text { justice. The offender can be } \\
\text { punished. }\end{array}$ & $\begin{array}{l}\text { Because of the tormentor's } \\
\text { anonymity, the victim cannot reply to } \\
\text { the offense. If this situation increases } \\
\text { his/her feeling of powerlessness, it } \\
\text { also intensifies the sensation of } \\
\text { impunity of the persecutor. }\end{array}$ \\
\hline
\end{tabular}

Today's individuals are confronted with "cannibalism of the eye" (Thomas 1984: 136), the devouring of their image without grasping any depth (Dilmaç 2014a \& 2014b). The image is only taken to the first degree; the individual represented can only appear in a reified form. The case of the Abu Ghraib Prison is a probing example: the photographic exposition of imprisoned soldiers half-naked, displayed like trophies to public viewing, was the pinnacle of humiliation through image. Reified both by their "pose" as humiliated and by their photographic representation, individuals are "delivered" (and no longer seen) to the eyes of anonymous Internet users. Their 
Dilmaç, J. A.(2014). Humiliation in the virtual world: Definitions and conceptualization. International Journal of Human Sciences, 11(2), 1285-1296. doi: 10.14687/ijhs.v1112.3036

reification is determined by an exterior aspect that has been imposed on them. The sharing of the latest images of Muammar Gaddafi during his capture is of the same order. Anonymous people also do not escape from these forms of humiliation: happy-slapping, which consists of posting online images of violent acts taken with a cell phone, is widespread and seems to be becoming generally accepted. The case of Jessica Leonhardt, better known by the name of "Jessy Slaughter" who was the victim of an entire viral phenomenon, after having posted several videos online, is another illustration of cyber-humiliation: she was insulted and victim of anonymous phone calls and pizza deliveries; the harassment went as far as posting prostitution advertisements' mentioning her home address.

Victims of cyber-humiliation have no way to get back: the recognition they seek is denied, and no opportunity is given to defend themselves. This situation forces victims to accept the posture of humiliated, the "loss of face" (Goffman 1990): their own self-image and that which is exposed to others are completely at odds.

\section{Conclusion}

In conclusion, devices such as webcams, and the habit of posting personal images, encourage individuals to divulge their private lives. Individuals exhibit themselves, accept to stand naked and in return they can be seen. Here, we have a relation between "voyeurism" and "exhibitionism". On the Internet, individuals accept to submit to others' "views" and comments; they accept to submit to avidity, to the "thirst" for this gaze: they aspire to be "commented," "shared," "liked," since it is others' gaze that brings you to light.

Nonetheless; if individuals align with this tyranny of opinion, it is because it allows reciprocity: they can also judge others. Through this, individuals construct themselves and situate themselves in the world, imposing themselves on other members. They actively participate in webs of sociability. Judgment established on the Internet can only respond to rules specific to the virtual world: since existence in the virtual world means existence in the eyes of others through our "avatar," a misappropriated or defamed image will have a considerable impact on the destruction of our "ereputation." This symbolic death sentence of e-reputation through anonymous judgment cannot be followed up by a reply, and thus is a form of humiliation and degradation. Through this, aggressors possess their victims, who are reduced to silence, while forcing them to look at their own humiliated images.

Even if it seems hard to find solutions to solve this problem, responses can be proposed to prevent cyber-humiliation: 
Dilmaç, J. A.(2014). Humiliation in the virtual world: Definitions and conceptualization. International Journal of Human Sciences, 11(2), 1285-1296. doi: 10.14687/ijhs.v11i2.3036

First of all, educating the individuals about how to use Internet but educating them about the danger and consequences of their actions as well could help. We need to address ways they can become inadvertent cyber bullies, how to be accountable for their actions and not to stand by and allow humiliation to be acceptable. Teaching individuals not to ignore the pain of others can also be a part of this education.

Secondly, talking about cyber-humiliation can be another way of preventing bullying: it could be a good solution to catch the attention of authorities. More campaigns could be organized to alert the general public to the risks of these kinds of interactions on the Internet.

Third, in the virtual world a new system has to be established to let individuals withdraw and erase the compromising pictures and comments shared in their name by others.

\section{References}

Ansart, P. (2006). "Les humiliations politiques". In Y. Déloye, \& C. Haroche (Eds.), Le sentiment d'bumiliation. In Press: 131-147.

Beauchere J. F. (2012).Preventing Online Bullying. What companies and Others can do. Microsoft Corporation.

[Online] Available:http://download.microsoft.com/download/2/8/281AEB96-EEBF-4255-9607DEBFFCF626DE/Preventing Online Bullying What Companies and Others Can Do Microsoft whitepaper.pdf

Carlson, B. E. (1987). Dating violence: A research review and comparison with spouse abuse. Soc. Casework: J. Contemp. Soc. Work: 16-23.

Davenport, N., Schwartz, R. D., \& Elliot, G. P. (2003).Mobbing: Emotional abuse in the American workplace. Amex, IO: Civil Society Publishing.

Dilmaç, J. A. (2014a). "Looking for the gaze: the case of humiliation in the Digital Era". Journal of Academic Inquiries, 1, 9, 183-204.

Dilmaç, J. A. (2014b). "Du regard qui jauge au regard qui juge : les nouvelles manières de regarder sur Internet". Influxus.

[Online] Available: http://www.influxus.eu/divers/de-l-oeil-au-regard/article/du-regard-qui-jaugeau-regard-qui?lang $=\mathrm{fr}$

Duncan, S. (2008). "MySpace is also their space: Ideas for keeping children safe from sexual predators on social-networking sites". Kentucky Law Journal. University of Louisville School of Law Legal Studies Research Paper Series No. 2008-13, 96.

Ellison, R. (1991). Invisible man. Penguin Classics.

Field, T. (2004). Bully online.

[Online] Available: http://www.bullying.co.uk

Goffman, E. (1955). “On Face-work: An Analysis of Ritual Elements of Social Interaction”. Psychiatry: Journal for the Study of Interpersonal Processes, 18, 3, 213-231.

Goffman, E. (1990). The Presentation of Self in Everyday Life. Penguin. 
Dilmaç, J. A.(2014). Humiliation in the virtual world: Definitions and conceptualization. International Journal of Human Sciences, 11(2), 1285-1296. doi: 10.14687/ijhs.v11i2.3036

Goodstein, A. (2007). Dangers Overblown for Teens Using Social Media.

[Online] Available: http://www.pbs.org/mediashift/2007/06/fear factordangers

Hackett, L. (2013). Annual bullying survey.

[Online] Available: http://www.ditchthelabel.org/downloads/Annual-Bullying-Survey-2013b.pdf.

Haroche, C. (2006). "L'appauvrissement intérieur de l'individu dans le capitalisme contemporain". In Y. Deloye\& C. Haroche (Eds.). Le sentiment d'bumiliation. In Press: 15-35.

Hecker, T. E. (2007). "Workplace mobbing: A discussion for librarians". The Journal of AcademicLibrarianship, 33, 4, 439-445.

Hirigoyen, M. F. (1998). Le harcèlement moral, la violence perverse au quotidien. Paris: La Découverte.

Hirigoyen, M. F. (2003). "Le harcèlement moral au travail en 2003". Le Journal International de Victimologie, 1, 1-10.

Hirigoyen, M-F. (2004). Stalking the Soul: Emotional Abuse and the Erosion of Identity. Helen Marx Books.

Jarreta, B. M., Campayo, J., Gascon, S., \&Bolea, M. (2004)."Medico-legal implications of mobbing: A false accusation of psychological harassment at the workplace". Forensic Science International, 146, 17-18.

Juvonen, J., Gross, E. F. (2008). "Extending the school grounds? Bullying experiences in cyberspace". J. Sch. Health, 78, 9, 496-505.

Kilic, E. D. (2009). "Psychological violence in learning organizations: A case study in Sanliurfa, Turkey". Social Behavior and Personality, 37, 7, 869-879.

Kiriakidis, S. P., Kavoura, A. (2010). "Cyberbullying: a review of the literature on harassment through the Internet and other electronic means". Family and Community Health, 33, 2, 82-93.

Leymann, H. (1996). Mobbing: La persécution au travail. Paris: Seuil.

National Crime Prevention Council. [Online] Available: http://www.ncpc.org/

Olweus, D. (1993). Bullying at school: What we know and what we can do. Oxford: Blackwell.

Pujazon-Zazik M., Park, M. J. (2010).“'To tweet, or not to tweet: gender differences and potential positive and negative health outcomes of adolescents' social internet use". American Journal of Men's Health, 4, 1, 77-85.

Quigley R., 2013, 'Yes I bullied her, she killed herself and I don't give a ****': girls, 12 and 14, whose cyber-stalking' drove fellow pupil, 12, to suicide' are arrested.

[Online] Available:http://www.dailymail.co.uk/news/article-246099/Rebecca-Ann-Sedwicksuicide-2-girls-aged-12-14-arrested-stalking.html

Rigby, K. (1997). Bullying in school and what to do about it. British edition: London, Jessica Kingsley.

Rigby, K. (2002). New perspectives on bullying. London: Jessica Kingsley.

Rivers, I. \& Noret, N. (2009). "Ih8u": Findings from a five-year study of text and e-mail bullying. British Educational Research.

Schneider M., Kay J., 2013, Rebecca Ann Sedwick Suicide: Two girls arrested for 'Terrorizing' bullied victim.

[Online] Available:http://www.huffingtonpost.com/2013/10/15/rebecca-annsedwick n $\underline{4100350 . \mathrm{html}}$ 
Dilmaç, J. A.(2014). Humiliation in the virtual world: Definitions and conceptualization. International Journal of Human Sciences, 11(2), 1285-1296. doi: 10.14687/ijhs.v11i2.3036

Sengupta, A., \& Chaudhuri, A. (2011).“Are social networking sites a source of online harassment for teens? Evidence from survey data". Children and Youth Services Review, 33, 284-290.

Slonge, R., \& Smith, P. K. (2008).“Cyberbullying: Another main type of bullying?”.Scandinavian Journal of Psychology, 49, 147-154.

Smith, P. K., \& Sharp, S. (1994). School bullying: Insights and perspectives. London: Routledge.

Smith, P. K., \& Mahdavi, J., \& Carvalho, M., \& Tippett, N. (2006). An investigation into cyberbullying, its forms, awareness and impact, and the relationship between age and gender in cyberbullying. Research Brief, No. RBX03-06. dFes, London.

Sourander, A., BrunsteinKlomek A., Ikonen M., Lindroos J., Luntamo T., Koskelainen M., et al. (2010). "Psychosocial risk factors associated with cyberbullying among adolescents: a population-based study". Archives of General Psychiatry, 67, 7, 720-728.

Sticca, F., Perren, S. (2013). "Is Cyberbullying worse than traditional bullying? Examining the differential roles of medium publicity, and anonymity for the perceived severity of bullying". Journal of Youth and Adolescent, 42, 5, 739-750.

Stopbullying. [Online] Available: http://www.stopbullying.gov/

Suzuki K., Asaga R., Sourander A., Hoven C. W., \&Mandell D. (2012). "Cyberbullying and adolescent mental health". International Journal of Adolescent Medicine and Health, 24, 1, 27-35.

Thomas, L. V. (1984). Fantasmes au quotidien. Librairie des Méridiens, Paris.

Tokunaga, R. S. (2010). "Following you home from school: A critical review and synthesis of research on cyberbullying victimization". Computers in HumanBehavior, 26, 3, 277-287.

Uhl, M. (2002). "Intimité panoptique. Internet ou la communication absente". Cabiers internationaux de sociologie. Presses universitaires de France, 1, 112, 151-168. 